\title{
Knowledge and perceptions about generic drugs by users of PSF in triple borders
}

\section{Conhecimento e uso de medicamentos genéricos por usuários do sistema único de saúde brasileiro em região de tríplice fronteira}

Laiz Mangini Cicchelero' ${ }^{10}$, Ana Paula Contiero Toninato² (D, Rosane Meire Munhak da Silva² (D), Jossiana Wilke Faller ${ }^{2}$ (D), Diogo Francisco Rossoni ${ }^{3}$ (D), Jackson Luiz Domareski' (D), Reinaldo Antônio Silva-Sobrinho² (D), Adriana Zilly² (D)

${ }^{1}$ Faculdade União Dinâmica Cataratas (UDC) - Foz do Iguaçu (PR), Brasil.

2 Universidade Estadual do Oeste do Paraná (UNIOESTE) - Foz do lguaçu (PR), Brasil.

${ }^{3}$ Universidade Estadual de Maringá (UEM) - Maringá (PR), Brasil.

How to cite: Cicchelero LM, Toninato APC, Silva RMM, Faller JW, Rossoni DF, Domareski JL et al. Knowledge and perceptions about generic drugs by users of PSF in triple borders. Cad Saúde Colet, 2020;28(2):260-270. https://doi. org/10.1590/1414-462X202028020266

\begin{abstract}
Background:The Brazilian Ministry of Health, by the National Policy on Medication, Ordinance 3916 from October $30^{\text {th }} 1998$, reinforces the Law of Generics of February 1999 (Law No. 9787 from February $10^{\text {th }}, 1999$, aiming, among other things, to reduce the prices and make access to medications easier for population). Objective: The main objective was to identify the level of knowledge of the population regarding generic drugs. Method: Descriptive, quantitative study, with 520 users interviewed in four health care units that implemented the Brazilian Family Health Program. Such units represent four health districts in Foz do Iguaçu, PR, Brazil. Results: Most of the interviewed know and/or have heard about generic drugs. For many people, the generic drug represents only a more affordable type of medication. Conclusion: The need for health education to clarify the population's questions was found, so they could identify and acquire their medication safely and with confidence.
\end{abstract}

Keywords: generic drugs; pharmacoepidemiology; Family Health Program.

\section{Resumo}

Introdução: O Ministério da Saúde, pela Política Nacional de Medicamentos, Portaria $\mathrm{n}^{\circ}$ 3.916, de 30 de outubro de 1998, reforça a Lei de Genéricos de fevereiro de 1999 (Lei n 9.787, de 10 de fevereiro de 1999, visando, entre outras coisas, reduzir os preços e facilitar o acesso aos medicamentos para a população). Objetivo: Identificar o nível de conhecimento da população em relação aos medicamentos genéricos. Método: Estudo descritivo, quantitativo, com 520 usuários entrevistados em quatro unidades de saúde que implementaram o Programa Saúde da Família e que representam quatro distritos sanitários de saúde em Foz do Iguaçu (PR), Brasil. Resultados: A maioria dos entrevistados conhece e/ou já ouviu falar do genérico. Para muitas pessoas, o medicamento genérico representa apenas um tipo de medicamento mais acessível. Conclusão: Achados indicam a necessidade de educação em saúde para esclarecer a população, para que possam identificar e adquirir seus medicamentos com segurança e confiança.

Descritores: medicamentos genéricos; farmacoepidemiologia; Programa Saúde da Família.

Study carried out at Family Health Units in the city of Foz do Iguaçu (PR), Brazil.

Correspondence: Adriana Zilly. E-mail: aazilly@hotmail.com

Financial support: none.

Conflict of interests: nothing to declare.

Received on: Nov. 09, 2017. Accepted on: Jul. 16, 2019.

\section{(c) (i)}

This is an Open Access article distributed under the terms of the Creative Commons Attribution License, which permits unrestricted use, distribution, and reproduction in any medium, provided the original work is properly cited. 


\section{INTRODUCTION}

In Brazil, it is the responsibility of the State to formulate and execute the economic and social policies proposed to establish conditions that ensure universal access to actions and services for promotion, protection, and recovery of health ${ }^{1}$. To fulfill this role concerning the use of pharmaceuticals, the National Policy on Medication (NPM) was set into practice through Ordinance 3916 of the 30th of October 1998, which is composed of a set of guidelines that aim to promote the improvement of health care of the population, ensuring access to essential medicines as well as the necessary safety, efficiency, and quality².

To stimulate competition and variety of supply on the market, improve the quality of pharmaceutical products, lower the prices and make access to treatments easier, in February of 1999 the Law of Generic Medication (MG) came into effect in the form of Law No. 9787, in the $10^{\text {th }}$ of February of $1999^{3}$, which have a lower cost than the reference medicines because the expenditures of the development of the molecule and the necessary clinical studies and investments in advertising need not be allocated to generic medication ${ }^{4}$.

Generic Medicines have the same active ingredient in the same dose and the same pharmaceutical formula, being administered the same way and with the same therapeutic indication of the reference medicine, as they can be interchangeable. In general, they are produced after the expiration or waiver of patent protection or other exclusive rights, provided that it has proven its effectiveness, safety, and quality 5 .

According to the authors, the similar medicine has the same characteristics and may differ only in characteristics relating to the size and shape of the product, shelf life, packaging, labeling, excipients and carriers, and must always be identified by a commercial name or trade mark ${ }^{6}$.

A common difficulty for consumers is to distinguish generic medicines from similar drugs or popular brand medicines. The more important and simpler information is in the packaging, which has a yellow stripe, containing a large letter $\mathrm{G}$ and the inscription "Generic Drug" followed by the number of the Law, so the generic is identified only by its active principle and has no brand name.

Since the year 1999 'till today, various decrees, ordinances, and resolutions were published to make the product registration easier, regulate the production, standardize the tests of quality and of bioequivalence, and to stimulate trade in generics in the country, which involved some actions such as the extinction of similar drugs with the name of the active principle, the creation of differentiated packaging, informational campaigns for the population and actions to promote them to the members of the medical profession ${ }^{4,7}$.

However, literature related to this topic has shown mostly studies of bioavailability and bioequivalence of drugs, price differences between the pharmaceutical specialties, and qualitative studies of the social representations of health professionals and users about generic drugs. But there are a few investigations about the knowledge, reliability, and acceptability of these products in society ${ }^{8}$.

Investigations on the prevalence of the use of generics and associated factors are needed, especially in areas of Family Health Strategy (ESF) - a reorganizer of the health care model in the Public Health System (SUS), which currently covers $53.1 \%$ of the Brazilian population?.

The consumer's rights for generic drugs involve both the premise to know and have access to these products of guaranteed quality and more affordable pricing, and the need to ensure a competitive market for pharmaceutical products ${ }^{10}$, thus financially facilitating access to treatment by different profiles of Brazilian consumers.

Considering the above, this study aimed to identify the level of knowledge of the population regarding generic drugs; to check the means of recognition of these medicines, and the socio-demographic factors that interfere with acquisition and recognition. 


\section{METHOD}

\section{Type of research}

A descriptive quantitative approach.

\section{Design and scenario of the study}

Cross-sectional design held in Foz do Iguacu, the western region of Paraná state, which has a population of 255,718 inhabitants, and is divided into five sanitary districts having 27 Basic Health Units, 16 of them being assisted by the Family Health Program (PSF), with a total of 32 teams from the Family Health Strategy (ESF), which cover $40 \%$ of the population ${ }^{11}$.

\section{Subjects of the study}

The study was conducted with individuals older than 18 years old, users of health units with PSF of the municipality, and who agreed to participate voluntarily in the research. Refusals were respected, and even those who felt uncomfortable or invaded in their privacy during the interview, could at any time interrupt their participation in the research.

The sample size was calculated from the total number of individuals enrolled in the ESF, with an estimated error of $5 \%$ and a reliability of $95 \%$, plus $20 \%$ for possible losses. Through proportional stratified sampling in which DS, the number of individuals in each district to be included in the study was defined, resulting in a total sample of 520 subjects.

For the collection, one unit with ESF per health district was chosen and four districts met this criterion of inclusion: DSI, DS II, DS III and DS IV (the DSV does not have an ESF program), and the chosen unit within each district was the one with the largest numbers of family follow-ups in 2012, according to the information of the Primary Care Information System (SIAB). Thus, the units chosen in four sanitary districts totaled 28,353 visits in 2012.

Thus, for the health service selected in DS I (7,399 follow-ups in 2012), the percentage was $26.1 \%$, for DS II $(8,212$ follow-ups in 2012$)$ it was $29 \%$, for DS III $(7,754$ follow-ups in 2012$)$ it was $27.3 \%$ and for DS IV (4,494 follow-ups in 2012$)$ it was $17.6 \%$ of the total respondents. Thus, there were interviewed over the sampling: 136 individuals in DS I; 151 individuals in DS II; 142 individuals in DS III and 91 individuals in DS IV, a total population of 520.

\section{Instrument and data collection}

We collected the data between October 2009 and March 2010, within the health center, through a structured interview with 16 closed-ended questions addressing socioeconomic data and information of the interviewee about Generic Drugs (GD). The questions were guided as follows: if the person knows GD; what does the person know about it; if the person has already used any GD; if they trust in this group of medicines and if they accept the replacement of reference/brand medicines for the generic.

\section{Data analysis}

Variables were dichotomized to conduct the statistical analysis, assigning 1 for yes and 0 for no. Independent variables in the study we categorized and dichotomized as follows: gender (male and female), age (age group), education (illiterate, complete or incomplete elementary education, and complete or incomplete secondary education and complete or incomplete higher education, greater than or equal to and less than 8 years of study), family income ( $\leq 1$ minimum wage $(\mathrm{MW}), \geq 2 \mathrm{MW}$ and $\geq 3 \mathrm{MW}$ ).

The collected data were recorded in an Excel spreadsheet, and logistic regression was used to implement the statistical analysis. After adjusting the model, the Stepwise procedure was applied as a modification of the Forward selection in which every step of the variables in the model is checked in advance by their $\mathrm{F}$ partial statistics. A variable added to the model in the previous step can be redundant to the model due to its relation with the other variables 
and if their $\mathrm{F}$ statistical partial is less than $F_{\text {out }}$, it is removed from the model. Some algorithms use Akaike (AIC) for selecting the final model.

All statistical analyzes were performed in R software ${ }^{12}$.

\section{Ethical aspects}

The study complied with the ethical principles contained in Resolution No. 466/2012 on research involving human beings ${ }^{13}$ with the assent of the Ethics Committee in Research (CEP) of Unioeste, Paraná, under No CAAE 14953513.6.0000.0107.

\section{RESULTS AND DISCUSSIONS}

Of the 520 interviewed participants, $69 \%$ were female, with a predominance of the age ranging from 18 to 38 (44\%) and with monthly income lower than or equal to the minimum wage $(60.4 \%)$. As for education, $51 \%$ have completed elementary school and only $6 \%$ said they have a higher education degree (Table 1).

Table 1. Socio-economic profile of users of the PSF, by health district in Foz do Iguacu/PR, 2010

\begin{tabular}{|c|c|c|c|c|c|c|c|c|c|c|}
\hline \multirow[t]{2}{*}{ Variable } & \multicolumn{2}{|c|}{$\begin{array}{c}\text { DSI } \\
n=136\end{array}$} & \multicolumn{2}{|c|}{$\begin{array}{c}\text { DS II } \\
n=151\end{array}$} & \multicolumn{2}{|c|}{$\begin{array}{c}\text { DS III } \\
n=142\end{array}$} & \multicolumn{2}{|c|}{$\begin{array}{l}\text { DS IV } \\
n=92\end{array}$} & \multicolumn{2}{|c|}{$\begin{array}{c}\text { Total } \\
n=520\end{array}$} \\
\hline & $\mathbf{N}$ & $\%$ & $\mathbf{N}$ & $\%$ & $\mathbf{N}$ & $\%$ & $\mathbf{N}$ & $\%$ & $\mathbf{N}$ & $\%$ \\
\hline \multicolumn{11}{|l|}{ Gender } \\
\hline Female & 100 & 73.5 & 107 & 70.9 & 102 & 71.8 & 50 & 54.9 & 359 & 69.0 \\
\hline Male & 36 & 26.5 & 44 & 29.1 & 40 & 28.2 & 41 & 45.1 & 161 & 31.0 \\
\hline \multicolumn{11}{|l|}{ Age Group } \\
\hline $18-38$ & 53 & 39.0 & 86 & 57.0 & 50 & 35.2 & 40 & 44.0 & 229 & 44.0 \\
\hline $39-59$ & 51 & 37.5 & 42 & 27.8 & 61 & 43.0 & 38 & 41.8 & 192 & 37.0 \\
\hline $60-80$ & 32 & 23.5 & 23 & 15.2 & 31 & 21.8 & 13 & 14.3 & 99 & 19.0 \\
\hline \multicolumn{11}{|l|}{ Monthly Income } \\
\hline$\geq 1$ Min. Wage & 72 & 52.9 & 116 & 76.8 & 70 & 49.3 & 56 & 61.5 & 314 & 60.4 \\
\hline$\geq 2$ Min. Wage & 53 & 39.0 & 35 & 23.2 & 62 & 43.7 & 24 & 26.4 & 174 & 33.5 \\
\hline$>3$ Min. Wage & 11 & 8.1 & 0 & 0 & 10 & 7.0 & 11 & 12.1 & 32 & 6.1 \\
\hline \multicolumn{11}{|l|}{ Education } \\
\hline Elementary & 68 & 50.0 & 101 & 66.9 & 67 & 47.2 & 29 & 31.9 & 265 & 51.0 \\
\hline Middle School & 57 & 41.9 & 42 & 27.8 & 56 & 39.4 & 44 & 48.4 & 199 & 38.3 \\
\hline Higher Education & 5 & 3.7 & 1 & 0.7 & 9 & 6.3 & 16 & 17.6 & 31 & 6.0 \\
\hline Nothing & 6 & 4.4 & 7 & 4.6 & 10 & 7.0 & 2 & 2.2 & 25 & 4.8 \\
\hline
\end{tabular}

This low level of education is still striking among the users of the public health service, which often prevents these individuals from claiming better health care services. These data are similar to other studies carried out with users of the ESF (Family Health Strategy) regarding the use of generic medicines, identifying most of them as illiterate and with $1^{\text {st }}$ elementary grade incomplete ${ }^{14}$.

Concerning the knowledge about generic drugs, the analysis revealed that $92.3 \%$ had already heard and/or knew about Generic Drugs, but only 53.9\% knew how to correctly identify it by the yellow stripe with the letter $\mathrm{G}$ instead of only by price or the name of the substance, showing homogeneity in the sanitary districts mentioned (Table 2). 
Table 2. Knowledge and confidence in generic medicine per users of the ESF, by health district in Foz do Iguacu/PR, 2010

\begin{tabular}{|c|c|c|c|c|c|c|c|c|c|c|}
\hline \multirow{2}{*}{ Variable } & \multicolumn{2}{|c|}{$\underset{n=136}{\text { DS I }}$} & \multicolumn{2}{|c|}{$\begin{array}{c}\text { DS II } \\
n=151\end{array}$} & \multicolumn{2}{|c|}{$\begin{array}{c}\text { DS III } \\
n=142\end{array}$} & \multicolumn{2}{|c|}{$\begin{array}{l}\text { DS IV } \\
n=92\end{array}$} & \multicolumn{2}{|c|}{$\begin{array}{c}\text { Total } \\
\mathbf{n}=\mathbf{5 2 0}\end{array}$} \\
\hline & $\mathbf{N}$ & $\%$ & $\mathbf{N}$ & $\%$ & $\mathbf{N}$ & $\%$ & $\mathbf{N}$ & $\%$ & $\mathbf{N}$ & $\%$ \\
\hline \multicolumn{11}{|c|}{$\begin{array}{l}\text { Know/already } \\
\text { heard of Generic } \\
\text { drugs }\end{array}$} \\
\hline Yes & 134 & 98.5 & 124 & 82.1 & 131 & 92.3 & 92 & 100 & 480 & 92.3 \\
\hline No & 2 & 1.5 & 26 & 17.2 & 11 & 7.7 & 0 & 0 & 39 & 7.5 \\
\hline N/A & 0 & 0 & 1 & 0.7 & 0 & 0 & 0 & 0 & 1 & 0.2 \\
\hline \multicolumn{11}{|l|}{$\begin{array}{l}\text { If known. who } \\
\text { Informed }\end{array}$} \\
\hline TV/Radio & 54 & 39.7 & 56 & 37.1 & 46 & 32.4 & 62 & 67.4 & 218 & 41.8 \\
\hline Pharmacist & 57 & 41.9 & 16 & 10.6 & 58 & 40.8 & 00 & 00 & 131 & 25.1 \\
\hline Doctor & 16 & 11.8 & 47 & 31.1 & 13 & 09.2 & 10 & 10.9 & 86 & 16.5 \\
\hline Other & 7 & 5.2 & 28 & 18.5 & 25 & 17.6 & 17 & 18.5 & 77 & 14.8 \\
\hline Newspaper & 1 & 0.7 & 03 & 2.0 & 0 & 0 & 0 & 0 & 4 & 0.8 \\
\hline Internet & 1 & 0.7 & 01 & 0.7 & 0 & 0 & 03 & 3.2 & 5 & 1.0 \\
\hline \multicolumn{11}{|l|}{$\begin{array}{l}\text { Has the same } \\
\text { Substance }\end{array}$} \\
\hline Yes & 89 & 65.4 & 69 & 45.7 & 91 & 64.1 & 85 & 93.4 & 334 & 64.2 \\
\hline No & 44 & 32.4 & 56 & 37.1 & 45 & 31.7 & 6 & 6.6 & 146 & 28.1 \\
\hline N/A & 3 & 2.2 & 26 & 17.2 & 6 & 4.2 & 0 & 0 & 40 & 7.7 \\
\hline \multicolumn{11}{|l|}{$\begin{array}{l}\text { Has the same } \\
\text { Effect }\end{array}$} \\
\hline Yes & 86 & 63.2 & 97 & 64.2 & 90 & 63.4 & 83 & 91.2 & 357 & 68.5 \\
\hline No & 47 & 34.6 & 28 & 18.5 & 46 & 32.4 & 6 & 6.6 & 122 & 23.4 \\
\hline N/A & 3 & 2.2 & 26 & 17.2 & 6 & 4.2 & 2 & 2.2 & 42 & 8.1 \\
\hline \multicolumn{11}{|c|}{ Has the same Price } \\
\hline Yes & 126 & 92.6 & 121 & 80.1 & 115 & 81 & 88 & 96,7 & 425 & 81,7 \\
\hline No & 8 & 5,9 & 4 & 2,6 & 11 & 7,7 & 0 & 0 & 53 & 10,2 \\
\hline $\mathrm{N} / \mathrm{A}$ & 2 & 1,5 & 26 & 17,2 & 16 & 11,3 & 3 & 3,3 & 42 & 8,1 \\
\hline \multicolumn{11}{|l|}{$\begin{array}{l}\text { How Generic is } \\
\text { Identified }\end{array}$} \\
\hline Yellow Stripe & 83 & 61.0 & 83 & 55.0 & 54 & 38.0 & 61 & 66.3 & 281 & 53.9 \\
\hline Price & 42 & 30.9 & 20 & 13.2 & 03 & 02.1 & 25 & 27.2 & 90 & 17.3 \\
\hline Substance & 7 & 5.2 & 22 & 14.6 & 74 & 52.1 & 6 & 6.5 & 109 & 20.9 \\
\hline N/A & 4 & 2.9 & 26 & 17.2 & 11 & 7.8 & 0 & 0 & 41 & 7.9 \\
\hline
\end{tabular}


Table 2. Continued...

\begin{tabular}{|c|c|c|c|c|c|c|c|c|c|c|}
\hline \multirow{2}{*}{ Variable } & \multicolumn{2}{|c|}{$\begin{array}{c}\text { DS I } \\
n=136\end{array}$} & \multicolumn{2}{|c|}{$\begin{array}{c}\text { DS II } \\
n=151\end{array}$} & \multicolumn{2}{|c|}{$\begin{array}{l}\text { DS III } \\
n=142\end{array}$} & \multicolumn{2}{|c|}{$\begin{array}{l}D S I V \\
n=92\end{array}$} & \multicolumn{2}{|c|}{$\begin{array}{c}\text { Total } \\
\mathbf{n}=\mathbf{5 2 0}\end{array}$} \\
\hline & $\mathbf{N}$ & $\%$ & $\mathbf{N}$ & $\%$ & $\mathbf{N}$ & $\%$ & $\mathbf{N}$ & $\%$ & $\mathbf{N}$ & $\%$ \\
\hline \multicolumn{11}{|l|}{ Used in the Past } \\
\hline Yes & 120 & 88.2 & 92 & 60.9 & 115 & 81.0 & 82 & 90.1 & 409 & 78.7 \\
\hline No & 14 & 10.3 & 38 & 25.2 & 21 & 14.8 & 8 & 8.8 & 81 & 15.6 \\
\hline N/A & 2 & 1.5 & 21 & 13.9 & 6 & 4.2 & 1 & 1.1 & 30 & 5.8 \\
\hline \multicolumn{11}{|c|}{$\begin{array}{l}\text { Long term use of } \\
\text { generics }\end{array}$} \\
\hline Yes & 66 & 48.5 & 54 & 35.8 & 64 & 45.1 & 52 & 56.5 & 236 & 45.3 \\
\hline No & 68 & 50.0 & 80 & 52.9 & 73 & 51.4 & 40 & 43.5 & 261 & 50.1 \\
\hline N/A & 2 & 1.5 & 17 & 11.3 & 05 & 3.5 & 0 & 0 & 24 & 4.6 \\
\hline \multicolumn{11}{|c|}{$\begin{array}{l}\text { Doctors prescribed } \\
\text { Generic Drugs }\end{array}$} \\
\hline No & 90 & 66.2 & 65 & 43.1 & 60 & 42.3 & 13 & 14.1 & 228 & 43.8 \\
\hline 1 to 2 & 40 & 29.4 & 86 & 56.9 & 69 & 48.6 & 63 & 68.5 & 258 & 49.5 \\
\hline 3 or more & 5 & 3.7 & 0 & 00 & 9 & 6.3 & 16 & 17.4 & 30 & 5.8 \\
\hline N/A & 1 & 0.7 & 0 & 00 & 4 & 2.8 & 0 & 0 & 5 & 1.0 \\
\hline \multicolumn{11}{|c|}{$\begin{array}{l}\text { Where medicine is } \\
\text { acquired }\end{array}$} \\
\hline Health center & 75 & 55.1 & 111 & 73.5 & 118 & 83.1 & 59 & 64.8 & 363 & 69.8 \\
\hline Purchase & 61 & 44.9 & 40 & 26.5 & 24 & 16.9 & 32 & 35.2 & 157 & 30.2 \\
\hline \multicolumn{11}{|l|}{$\begin{array}{l}\text { How many } \\
\text { purchased per } \\
\text { month }\end{array}$} \\
\hline Non & 20 & 14.7 & 45 & 29.8 & 38 & 26.8 & 14 & 15.2 & 117 & 22.5 \\
\hline 1 to 3 & 98 & 72.1 & 97 & 64.2 & 101 & 71.1 & 72 & 78.3 & 368 & 70.6 \\
\hline 4 or more & 18 & 13.2 & 9 & 06.0 & 3 & 2.1 & 6 & 6.5 & 36 & 6.9 \\
\hline \multicolumn{11}{|c|}{$\begin{array}{l}\text { Has compared } \\
\text { BrandX-Generic }\end{array}$} \\
\hline Yes & 88 & 64.7 & 70 & 46.4 & 111 & 78.2 & 78 & 84.8 & 347 & 66.6 \\
\hline No & 46 & 33.8 & 53 & 35.1 & 22 & 15.5 & 14 & 15.2 & 135 & 25.9 \\
\hline N/A & 2 & 1.5 & 28 & 18.5 & 9 & 6.3 & 0 & 00 & 39 & 7.5 \\
\hline \multicolumn{11}{|l|}{ Trusts Generic } \\
\hline Yes & 98 & 72.1 & 105 & 69.5 & 93 & 65.5 & 88 & 96.7 & 384 & 73.8 \\
\hline No & 35 & 25.7 & 26 & 17.2 & 38 & 26.8 & 3 & 3.3 & 96 & 18.5 \\
\hline N/A & 3 & 2.2 & 20 & 13.2 & 11 & 07.7 & 0 & 0 & 40 & 7.7 \\
\hline \multicolumn{11}{|l|}{$\begin{array}{l}\text { Accepts the } \\
\text { interchange- } \\
\text { ability }\end{array}$} \\
\hline Yes & 101 & 74.3 & 115 & 76.2 & 66 & 46.5 & 85 & 93.4 & 354 & 68.1 \\
\hline No & 32 & 23.5 & 17 & 11.3 & 64 & 45.1 & 6 & 6.6 & 125 & 24.0 \\
\hline N/A & 3 & 2.2 & 19 & 12.6 & 12 & 8.5 & 0 & 0 & 41 & 7.9 \\
\hline
\end{tabular}


The Brazilian government saw the need to create a different visual identity for the Generic Drugs, to facilitate its identification by the consumer and the distinction between similar medicines. Simultaneously, ANVISA was preparing the launch of a new logo for generic drugs to make the marketing of similar drugs without brand name more effective. This strategy has achieved the expected results ${ }^{4}$. In several studies carried out in Brazil, most the consumers indicated that the letter " $G$ " on the packaging was cited to be what was most recalled for identifying a generic drug ${ }^{15-17}$.

Regarding mass media, which is the main vehicle to inform the general public, TV/radio was singled out as the one that tells you about the "generic" (41.8\%), followed by the pharmacists with $25.1 \%$ (Table 2). These indices indicate, from the perspective of the user, that they still get more information from the media than from the health-care professionals; the active and conscious participation of professionals responsible for prescribing and dispensing it is essential to clarify the doubts of consumers ${ }^{18}$. Only through knowledge can one ensure that the patient feels safe about what he/she consumes, aiming to re-establish their health and well-being.

As far as the variable how do you define the generic drug, there was an inquiry as to the comparison aspects of the reference drug: the generic has the same substance as the brand name medicine: $64.2 \%$ stated that yes; $68.5 \%$ believed the generic brand has the same effect, and the generic brand is of lesser cost: $81.7 \%$ used this characteristic to define it (Table 2).

Although almost $70 \%$ of respondents buy their medicines at the basic health unit, the same proportion of people (70.6\%) still buy 1 to 3 medicines/month at drugstores (Table 2).

The medicines play a key role in health care, provided that they are accessible and that they are provided and used rationally ${ }^{19}$.

In Brazil, pharmaceuticals had the largest weight at total household expenditure, when it comes to health care expenses, growing from $44.9 \%$ in 2003 to $48.6 \%$ in 2009 . The families with the lowest income spend approximately twice more with drugs than those with higher incomes, which invest more resources in health plans ${ }^{11}$.

Although the professionals who work in drugstores are aware and have positive confidence concerning the generic drugs, many still choose not to indicate this similar type due to "bonus" on sales ${ }^{16,20}$.

When addressed the question of reliability, in Table $2,73.8 \%$ believed in the quality of generic and $68.1 \%$ said they accept the interchangeability, i.e. the exchange of the reference drug for its corresponding generic made by a professional pharmacist, which seems to be motivated by experiences of usage by the interviewed people.

The process of dissemination of reference and similar pharmaceutical products between the prescribers is overall more dynamic due to persuasive means of the laboratories of these groups, through representatives and media in general ${ }^{16}$.

As far as the statistical analyzes, we proceeded with the logistic regression the response variable "Has the same substance" which predictor independent variables. With this analysis, it was found that the questions "Has the same effect", "How many purchases per month" and "Accepts the replacement by drugstore" were significant at 5\% significance level, i.e., they significantly influence the response variable in DSI. After this, Stepwise procedure was applied, in which that the selected model showed the same results of complete regression (Table 3).

For the DS II, the response variable "Has the same substance" was influenced by the questions "Who informed", "Has the same effect" and "Already compared brand". By applying Stepwise procedure, the question "Who informed" was not significant at the $5 \%$ significance and the question "monthly income" proved to be significant, i.e. this population presents lower income than in other districts, which can confirm that the lower the income, the greater the difficulty to understand the Generics (Table 3).

In Ponta Grossa, PR in 2011, a survey on the scope of primary care, showed that almost all of the interviewees knew about the generic, suggesting the spread of the product in that population ${ }^{14}$.

When applied the analysis concerning the question "trusts the generic drug "in DSI, it was significantly influenced by the questions "has the same effect", "doctors prescribe Generic drugs" and "accepts the exchange by the drugstore". The same was confirmed by the model selected by Stepwise. In DS II, the same question was influenced by the question "who informed", "has the same effect", "how Generic drug is identified" and "how Generic is acquired", which is also confirmed in the Stepwise model selected (Table 4). 
Table 3. Significant variables regarding the understanding of the generic medicine on the part of users of the ESF in health districts in Foz do Iguacu/PR, 2010

\begin{tabular}{|c|c|c|c|c|c|c|c|c|c|c|c|}
\hline \multirow{2}{*}{ Variable } & \multicolumn{2}{|c|}{$\begin{array}{c}\text { DSI } \\
n=136\end{array}$} & \multirow{2}{*}{$\begin{array}{c}P \\
\text { value }\end{array}$} & \multicolumn{2}{|c|}{$\begin{array}{c}\text { DS II } \\
n=151\end{array}$} & \multirow{2}{*}{$\begin{array}{c}P \\
\text { Value }\end{array}$} & \multicolumn{2}{|c|}{$\begin{array}{l}D S \text { IV } \\
n=92\end{array}$} & \multirow{2}{*}{$\begin{array}{c}P \\
\text { Value }\end{array}$} & \multicolumn{2}{|c|}{$\begin{array}{l}\text { Total } \\
n=520\end{array}$} \\
\hline & $\mathbf{N}$ & $\%$ & & $\mathbf{N}$ & $\%$ & & $\mathbf{N}$ & $\%$ & & $\mathbf{N}$ & $\%$ \\
\hline Gender & & & 0.81 & & & 0.08 & & & $3.47^{-9}$ & & \\
\hline Female & 100 & 73.5 & & 107 & 70.9 & & 50 & 54.9 & & 359 & 69.0 \\
\hline Male & 36 & 26.5 & & 44 & 29.1 & & 41 & 45.1 & & 161 & 31.0 \\
\hline $\begin{array}{l}\text { Monthly } \\
\text { Income }\end{array}$ & & & 0.09 & & & 0.03 & & & 0.98 & & \\
\hline$\geq 1$ Min. Wage & 72 & 52.9 & & 116 & 76.8 & & 56 & 61.5 & & 314 & 60.4 \\
\hline$\geq 2$ Min. Wage & 53 & 39.0 & & 35 & 23.2 & & 24 & 26.4 & & 174 & 33.5 \\
\hline >3 Min. Wage & 11 & 8.1 & & 0 & 0 & & 11 & 12.1 & & 32 & 06.2 \\
\hline $\begin{array}{l}\text { If known. who } \\
\text { Informed }\end{array}$ & & & 0.38 & & & 0.02 & & & 0.99 & & \\
\hline TV/Radio & 54 & 39.7 & & 56 & 37.1 & & 62 & 67.4 & & 218 & 41.8 \\
\hline Pharmacist & 57 & 41.9 & & 16 & 10.6 & & 0 & 00 & & 131 & 25.1 \\
\hline Doctor & 16 & 11.8 & & 47 & 31.1 & & 10 & 10.9 & & 86 & 16.5 \\
\hline Other & 7 & 5.2 & & 28 & 18.5 & & 17 & 18.5 & & 77 & 14.8 \\
\hline Newspaper & 1 & 0.7 & & 3 & 2.0 & & 0 & 0 & & 4 & 0.8 \\
\hline Internet & 1 & 0.7 & & 1 & 0.7 & & 3 & 3.2 & & 5 & 1.0 \\
\hline $\begin{array}{l}\text { Has the same } \\
\text { Effect }\end{array}$ & & & $5.21^{-16}$ & & & $5.36^{-7}$ & & & 0.88 & & \\
\hline Yes & 86 & 63.2 & & 97 & 64.2 & & 83 & 91.2 & & 357 & 68.5 \\
\hline No & 47 & 34.6 & & 28 & 18.5 & & 6 & 6.6 & & 122 & 23.4 \\
\hline N/A & 3 & 2.2 & & 26 & 17.2 & & 2 & 2.2 & & 42 & 8.1 \\
\hline $\begin{array}{l}\text { How many } \\
\text { purchased } \\
\text { per month }\end{array}$ & & & 0.03 & & & 0.17 & & & 0.87 & & \\
\hline None & 20 & 14.7 & & 45 & 29.8 & & 14 & 15.2 & & 117 & 22.5 \\
\hline 1 to 3 & 98 & 72.1 & & 97 & 64.2 & & 72 & 78.3 & & 368 & 70.6 \\
\hline 4 or more & 18 & 13.2 & & 9 & 6.0 & & 6 & 6.5 & & 36 & 6.9 \\
\hline $\begin{array}{l}\text { Has compared } \\
\text { BrandX- } \\
\text { Generic }\end{array}$ & & & 0.93 & & & 0.02 & & & 0.85 & & \\
\hline Yes & 88 & 64.7 & & 70 & 46.4 & & 78 & 84.8 & & 347 & 66.6 \\
\hline No & 46 & 33.8 & & 53 & 35.1 & & 14 & 15.2 & & 135 & 25.9 \\
\hline N/A & 2 & 1.5 & & 28 & 18.5 & & 0 & 0 & & 39 & 7.5 \\
\hline $\begin{array}{l}\text { Accepts the } \\
\text { interchange- } \\
\text { ability }\end{array}$ & & & 0.002 & & & 0.90 & & & 0.98 & & \\
\hline Yes & 101 & 74.3 & & 115 & 76.2 & & 85 & 93.4 & & 354 & 68.1 \\
\hline No & 32 & 23.5 & & 17 & 11.3 & & 6 & 6.6 & & 125 & 24.0 \\
\hline $\mathrm{N} / \mathrm{A}$ & 3 & 2.2 & & 19 & 12.5 & & 0 & 0 & & 41 & 7.9 \\
\hline
\end{tabular}


Table 4. Significant variables regarding confidence in generic medicine on the part of users of the ESF in health districts in Foz do Iguacu/PR, 2010

\begin{tabular}{|c|c|c|c|c|c|c|c|c|c|c|c|}
\hline \multirow{2}{*}{ Variable } & \multicolumn{2}{|c|}{$\begin{array}{c}\text { DSI } \\
n=136\end{array}$} & \multirow{2}{*}{$\begin{array}{c}P \\
\text { value }\end{array}$} & \multicolumn{2}{|c|}{$\begin{array}{c}\text { DS II } \\
n=151\end{array}$} & \multirow{2}{*}{$\begin{array}{c}P \\
\text { value }\end{array}$} & \multicolumn{2}{|c|}{$\begin{array}{l}\text { DS IV } \\
n=92\end{array}$} & \multirow{2}{*}{$\begin{array}{c}P \\
\text { value }\end{array}$} & \multicolumn{2}{|c|}{$\begin{array}{c}\text { Total } \\
\mathrm{n}=\mathbf{5 2 0}\end{array}$} \\
\hline & $\mathbf{N}$ & $\%$ & & $\mathbf{N}$ & $\%$ & & $\mathbf{N}$ & $\%$ & & $\mathbf{N}$ & $\%$ \\
\hline Gender & & & 0.60 & & & 0.28 & & & $3.47^{-9}$ & & \\
\hline Female & 100 & 73.5 & & 107 & 70.9 & & 50 & 54.9 & & 359 & 69.0 \\
\hline Male & 36 & 26.5 & & 44 & 29.1 & & 41 & 45.1 & & 161 & 31.0 \\
\hline $\begin{array}{l}\text { If known. who } \\
\text { informed }\end{array}$ & & & 0.44 & & & 0.02 & & & 0.99 & & \\
\hline TV/Radio & 54 & 39.7 & & 56 & 37.1 & & 62 & 67.4 & & 218 & 41.8 \\
\hline Pharmacist & 57 & 41.9 & & 16 & 10.6 & & 00 & 00 & & 131 & 25.1 \\
\hline Doctor & 16 & 11.8 & & 47 & 31.1 & & 10 & 10.9 & & 86 & 16.5 \\
\hline Other & 07 & 05.2 & & 28 & 18.5 & & 17 & 18.5 & & 77 & 14.8 \\
\hline Newspaper & 1 & 0.7 & & 3 & 2.0 & & 0 & 0 & & 4 & 0.80 \\
\hline Internet & 1 & 0.7 & & 1 & 0.7 & & 3 & 3.2 & & 5 & 1.0 \\
\hline Has the same effect & & & $1.21^{-10}$ & & & $5.36^{-7}$ & & & 0.88 & & \\
\hline Yes & 86 & 63.2 & & 97 & 64.2 & & 83 & 91.2 & & 357 & 68.5 \\
\hline No & 47 & 34.6 & & 28 & 18.5 & & 6 & 6.6 & & 122 & 23.4 \\
\hline $\mathrm{N} / \mathrm{A}$ & 3 & 2.2 & & 26 & 17.3 & & 2 & 2.2 & & 42 & 8.1 \\
\hline $\begin{array}{l}\text { How is Generic } \\
\text { identified }\end{array}$ & & & 0.23 & & & 0.007 & & & 1.11 & & \\
\hline Yellow Stripe & 83 & 61.0 & & 83 & 55.0 & & 61 & 66.3 & & 281 & 53.9 \\
\hline Price & 42 & 30.9 & & 20 & 13.2 & & 25 & 27.2 & & 90 & 17.3 \\
\hline Substance & 7 & 5.2 & & 22 & 14.6 & & 6 & 6.5 & & 109 & 20.9 \\
\hline N/A & 4 & 2.9 & & 26 & 17.2 & & 0 & 00 & & 41 & 7.9 \\
\hline $\begin{array}{l}\text { Doctors prescribed } \\
\text { Generic Drugs }\end{array}$ & & & 0.04 & & & 0.76 & & & 1.00 & & \\
\hline No & 90 & 66.2 & & 65 & 43.1 & & 13 & 14.1 & & 228 & 43.8 \\
\hline 1 to 2 & 40 & 29.4 & & 86 & 56.9 & & 63 & 68.5 & & 258 & 49.5 \\
\hline 3 or more & 5 & 3.7 & & 0 & 0 & & 16 & 17.4 & & 30 & 5.7 \\
\hline N/A & 1 & 0.7 & & 0 & 0 & & 0 & 0 & & 5 & 1.0 \\
\hline $\begin{array}{l}\text { Where is medicine } \\
\text { acquired }\end{array}$ & & & 0.94 & & & 0.01 & & & 1.11 & & \\
\hline Health center & 75 & 55.1 & & 111 & 73.5 & & 59 & 64.8 & & 363 & 69.8 \\
\hline Purchase & 61 & 44.9 & & 40 & 26.5 & & 32 & 35.2 & & 157 & 30.2 \\
\hline $\begin{array}{l}\text { Accepts the } \\
\text { interchangeability }\end{array}$ & & & $4.29^{-7}$ & & & 0.07 & & & 0.98 & & \\
\hline Yes & 101 & 74.3 & & 115 & 76.2 & & 85 & 93.4 & & 354 & 68.1 \\
\hline No & 32 & 23.5 & & 17 & 11.2 & & 6 & 6.6 & & 125 & 24.0 \\
\hline $\mathrm{N} / \mathrm{A}$ & 3 & 2.2 & & 19 & 12.6 & & 0 & 0 & & 41 & 7.9 \\
\hline
\end{tabular}


Results are similar to the study of ANVISA where $80 \%$ believed that they had the same effect as the reference pharmaceutical products and $71 \%$ agreed that the generic had lowest price ${ }^{4}$. In the city of Tubarão, SC, $76.9 \%$ of users said that generics have the same effect as the brand name products and $90 \%$ were satisfied with the result of the pharmaceutical product ${ }^{16}$.

Just knowing how to define a generic drug product gives the individual assuredness regarding the use of a product of the same substance and therapeutic effect as the commercial brand $^{15}$. It shows that there is a high rate of using price as a distinguishing feature; this can confuse the consumer in being able to differentiate the generics because "similar" pharmaceutical present on the market also relies on this component of sales for its expansion in the market. Noteworthy is the relevance of economic factors for consumers to purchase their medications, $66.7 \%$ have already researched price between the reference medicine (cited "brand" in this research) and the generic, also associated with the fact that $60.4 \%$ have an income lower than or equal to a minimum wage. The policy of generics has been one of the main governmental attempts to broaden the access of the population to medicines.

But in the case of a product related to the health of the citizens, the lack of more detailed information about the generic medicines can lead to suspicion about its quality and be related to the decision to not buy the product. The population should be more well-informed about the tests that prove the quality of the same, as the bioequivalence and bioavailability to which these medicines are subjected ${ }^{21}$.

We found that almost all of the interviewed participants, represented here by the people using SUS have heard about and/or know the generic medicine. After almost two decades of existence, this shows that the actions of dissemination were effective.

The understanding of the generic medicine by consumers/patients is represented as a product of the same substance, same therapeutic effect, and lower price; however, only part of the population that is knowledgeable of the term understands the characteristics that make the generic comparable to the reference product and know how to correctly identify it using visual perception (letter $\mathrm{G}$ ).

One of the main factors associated with the use of Generic drugs was the monthly income of the population, which directly interfered with the acquisition, or not, of the medicine, and not the knowledge about generic drugs, which indicated the need for health education for the population, so they can identify and safely purchase their medicines.

\section{REFERENCES}

1. Brasil. Lei n 8.080, de 19 de setembro de 1990. Dispõe sobre as condições para a promoção, proteção e recuperação da saúde, a organização e o funcionamento dos serviços correspondentes. Diário Oficial da União, Brasília, 20 de setembro de 1990.

2. Brasil. Portaria GM/MS nº. 3.916, de 30 de outubro de 1998. Aprova a Política Nacional de Medicamentos. Diário Oficial da União, Brasília, 10 novembro de 1998.

3. Brasil. Lei no 9.787, de 10 de fevereiro de 1999. Dispõe sobre a vigilância sanitária, estabelece o medicamento genérico, dispõe sobre a utilização de nomes genéricos em produtos farmacêuticos e dá outras providências. Diário Oficial da União, Brasília, 11 de fevereiro de 1999.

4. Dias CRC, Romano-Lieber NS. Processo da implantação da política de medicamentos genéricos no Brasil. Cad Saude Publica. 2006;22(8):1661-9. http://dx.doi.org/10.1590/S0102-311X2006000800014. PMid:16832537.

5. Mastroianni PC, Lucchetta RC. Regulamentação Sanitária de Medicamentos. Rev Cienc Farm Basica Apl. 2011;32(1):127-32.

6. Brasil. Ministério da Saúde. Agencia Nacional de Vigilância Sanitária. Resolução n 71, de 22 de dezembro de 2009. Estabelece regras para a rotulagem de medicamentos. Diário Oficial da União [Internet], Brasília, 23 de dezembro de 2009; Seção 1. [citado em 2013 de mar 17]. Disponível em: http://www.jusbrasil.com. br/diarios/1565695/dou-secao-1-23-12-2009-pg-75

7. Brasil. Ministério da Saúde. Agencia Nacional de Vigilância Sanitária. Medicamentos Similares Intercambiáveis. Diário Oficial da União, Brasília, 17 de setembro de 2018. Disponível em: http://portal. anvisa.gov.br/medicamentos-similares 
8. Carvalho MCRD, Junior HA, Raffin FN. Representações sociais de medicamento genérico por usuários. Rev bras ciênc farm. 2006;42(4):567-74.

9. Brasil. Ministério da Saúde. Departamento de Atenção Básica. Histórico de cobertura do PSF. Situação de Implantação de Equipes de Saúde da Família, Saúde Bucal e Agentes Comunitários de Saúde [Internet]. Brasília: Ministério da Saúde; 2011 [citado em 2013 abr 4]. Disponível em: https://sage.saude.gov.br/paineis/psf/lista_mun.php?output=html\&ufs=\&ibges=\&cg=\&tc=\&re_ giao $=\& r m=\& q s=\& u f c i d a d e=B r a s i l \& q t=5570 \% 20$ munic $\% C 3 \% A D p i o s \& p o p=206114067 \&$ cor $=005984 \&$ nonono=html\&title=\&mes=mar\%C3\%A7o\&mess=3\&anos=2017\&codPainel=31\&codPainel=31

10. Brasil. Ministério da Saúde. Agência Nacional de Vigilância Sanitária. Pesquisa nacional de opinião pública sobre medicamentos genéricos com consumidores [Internet]. Brasília: Ministério da Saúde; 2002 [citado em 2013 mar 20]. Disponível em: http://www.anvisa.gov.br/hotsite/genericos/index.htm

11. Instituto Brasileiro de Geografia e Estatística. IBGE Cidades 2012. Rio de Janeiro: Ministério do Planejamento, Orçamento e Gestão; 2012. [citado em 2013 abril 4]. Disponível em: http://www.ibge.gov.br/cidadesat/ painel/painel.php?codmun $=410830$

12. R Core Team. R: A language and environment for statistical computing [Internet]. Viena: R Foundation for Statistical Computing; 2012 [citado em 2013 abr 4]. Disponível em: http://www.r-project.org/

13. Brasil. Conselho Nacional de Saúde. Resolução n 466, de 12 de dezembro de 2012. Diário Oficial da União, Brasília, 13 de junho de 2012

14. Vosgerau MZ, Souza RK, Soares DA. Utilização de genéricos em área de atuação da equipe de Saúde da Família em município do sul do Brasil. Rev Bras Epidemiol. 2011;14(2):253-63. http://dx.doi.org/10.1590/ S1415-790X2011000200007. PMid:21655692.

15. Rocha CE, Barros JAC, Silva DP. Levantamento de dados sobre o conhecimento e informação acerca dos medicamentos genéricos em uma população de paciente do serviço de saúde ambulatorial do Recife, Pernambuco, Brasil. Cad Saude Publica. 2007;23(5):1141-50. http://dx.doi.org/10.1590/S0102311X2007000500016. PMid:17486236.

16. Blatt CR, Trauthman SC, Schmidt EH, Marchesan S, Silva LM, Martins JL. Conhecimento popular e utilização dos medicamentos genéricos na população do município de Tubarão, SC. Cad Saude Colet. 2012;17(1):7982. http://dx.doi.org/10.1590/S1413-81232012000100011.

17. Sousa CV, Mesquita JMC, Lara JE. Análise da decisão de compra de medicamentos frente à existência de produtos substitutos: um estudo no município de Belo Horizonte, Brasil. Ciênc Saúde Coletiva. 2013;18(11):3311-20.

18. Margonato FB. Atribuições do Farmacêutico na Política Nacional de Medicamentos. Infarma. 2006;18(3/4):28-31.

19. Reis WCT, Scopel CT, Correr CJ, Andrzejevski VMS. Análise das intervenções de farmacêuticos clínicos em um hospital de ensino terciário do Brasil. Einstein. 2013;11(2):190-6. http://dx.doi.org/10.1590/S167945082013000200010. PMid:23843060.

20. Lira CAB, Oliveira JNS, Andrade MS, Vancini-Campanharo CR, Vancini RL. Conhecimento, percepções e utilização de medicamentos genéricos: um estudo transversal. Einstein. 2014;12(3):267-73. http://dx.doi. org/10.1590/s1679-45082014ao3125. PMid:25295444.

21. Chiusoli $C L$, Pacagnan $M$, Souza MJB. Marketing social aplicado às políticas públicas: uma Pesquisa Longitudinal sobre o comportamento do consumidor de medicamentos genéricos [Internet]. Serv. Soc. Rev. 2007;10(1):sp. [citado em 201317 março]. Disponível em: http://www.uel.br/revistas/ssrevista/cv10n1.htm 